\title{
The Choice of Methodology and Techniques for the Analysis of the Krasnoyarsk Krai Population's Attitude Towards Climate Changes and New Energy Sources
}

\author{
Alexandra A. Sitnikova* \\ Siberian Federal University \\ 79 Svobodny, Krasnoyarsk, 660041, Russia
}

Received 14.07.2017, received in revised form 08.08.2017, accepted 23.08.2017

\begin{abstract}
The article describes the key methodological approaches and techniques of such sciences as environmental psychology, environmental sociology and environmental cultural studies. These are the historical approach, the bibliographic analysis, the activity-based approach with the social events design forming the personality's environmental consciousness, psychological diagnostics, sociological survey, collection of expert opinions, content analysis, etc. The choice of the methodology for the analysis of the Krasnoyarsk Krai population's attitude towards climate changes and new energy sources is based on the analysis of the advantages and disadvantages of various methodologies. The methodology for this analysis turned to be a synthetic one. It resulted from the work with L. Whitmarsh's survey for psychological diagnosis of the personality's environmental consciousness which was supplemented with the specific ecological problems of Krasnoyarsk Krai (air pollution from large industrial enterprises, introduction of "black sky" situation, consequences of the operation of the hydroelectric power station on the Yenisei river and other aspects) as well as from the design of the surveys of expert opinions - first, for the administrative managers (based on the surveys of the researchers E. Ojomo, M. Elliot, U. Amjad, J. Bartram for Southern Nigeria), and second, for the managers of large industrial enterprises (based on the European concrete platform survey).
\end{abstract}

Keywords: environmental psychology, environmental sociology, environmental cultural studies, psychological diagnostics of the personality's environmental consciousness, the Krasnoyarsk Krai population's attitude towards climate changes.

The reported study was funded by the Russian Foundation for Basic Research, Krasnoyarsk Krai Government, Krasnoyarsk Krai Science and Technology Support Fund to Research Project No. 1716-24601.

DOI: $10.17516 / 1997-1370-0146$.

Research area: culturology.

\section{Introduction}

The work in the field of environmental studies has been more and more intensive since 1960-s in Western science and since approximately 1990-s in Russian science. Nowadays there are a number of sciences in

(C) Siberian Federal University. All rights reserved

* Corresponding author E-mail address: sem_dobrianka@mail.ru 
the field of the personality's and the society's environmental consciousness development. These are environmental psychology, environmental sociology, environmental cultural studies and environmental pedagogy. Their emergence and introduction into educational programmes and research practice are linked to one of the greatest challenges of the 21 century, the challenge being climate changes recorded by the scientific community and actively discussed in the media and society because of active human impact on the environment in the conditions of urban life in the era of anthropocentrism and the need for a more competent management and settlement of this impact for the prosperous development of mankind in the future. Such problems as the population's environmental literacy development, the citizens' participation in the process of reducing an anthropogenic impact on the environment (abandonment of personal transport in favor of public one, economical and careful use of energy and water resources, participation in distribution and processing of waste, etc.), as well as the possibility of transition to less powerful but more environmentally friendly new energy sources are discussed in the framework of the environmental humanities. Whereas the most developed and advanced countries have already made a transition to new energy sources and, thus, have been implementing the programmes of recycling of waste, solving the problem of excessive distribution of personal transport, the developing countries have not made such a transition yet and the society is at the stage of acquaintance with the changes in progress. In Russian and especially Siberian society the problem of climate changes is only starting to be discussed and the first steps towards the development of public environmental consciousness are being made. Therefore, the scientific researches in the field of humanitarian ecology are especially relevant today. The present paper sets the goal of the development of the environmental cultural studies methodologies, which are currently not developed enough. In particular, the paper has solved such tasks as: 1) the description of methodological approaches and techniques in the humanities with an environmental focus; 2) the development and description of the advantages of the methodology for evaluating the Krasnoyarsk Krai population's attitudes towards climate changes.

As already noted, these issues are studied by the researchers in the framework of such a science as environmental psychology with J.J. Gibson and R.G. Barker as its founders. In Russia environmental psychology is developed by S.D. Deriabo, E.A. Sterligova, V.V. Glebov. In Russia such a scientific field as environmental sociology originates in V.I. Vernadsky's works and is currently developed by such researchers as V.A. Sitarov, V.V. Pustovoitov and others. In Western practice this science is called environmental sociology which was introduced by the researchers of "the Chicago school of human ecology" (R.E. Park, for example) and is currently developing (M.L. Redclift et al.). Environmental cultural studies in Russia has started developing quite recently. The researchers in this field are V.A. Ignatova, S.B. Ignatov. In Western science this field of knowledge is called differently: "cultural ecology" or "green cultural studies". It is developed by a number of the researchers - I.G. Simmons, J.A. Lauwerys, F. Berkes.

\section{Problem Statement}

In light of active development of new humanities focused on environmental issues of an interdisciplinary character, such as environmental psychology, environmental sociology, environmental cultural studies and others, there is a need to develop theoretical methodological approaches and applied 
techniques for the researches in the field of these sciences. The present paper solves the problem of search for the adequate and verifiable techniques for the analysis of the Krasnoyarsk Krai population's attitude towards climate changes and new energy sources.

\section{Methods}

The bibliographic method, a method of working with literary sources - monographs, textbooks, and cutting-edge scientific articles from the Scopus, Web of Science and RSCI databases, is applied in this paper for the analysis of modern methodological approaches and techniques. To solve the second problem - the choice and preparation of the technique to evaluate the Krasnoyarsk Krai population's attitude towards climate changes and new energy sources - the

techniques of psychological diagnostics of the personality's environmental consciousness and the methods of sociological survey being developed by such researchers as L. Whitmarsh and E. Ojomo, M. Elliot, U. Amjad, J. Bartram. The method of expert evaluation of the society's environmental consciousness development was applied in the course of the preparation of the sections with surveys of the managers of public authorities and heads of large industrial enterprises the activities of which have an impact on the environmental situation in Krasnoyarsk Krai.

\section{Discussion}

In modern science the problem of the analysis of the population's attitude towards climate changes and new sources of energy is a problem of such sciences as environmental psychology, environmental sociology and environmental cultural studies. The main methodological approaches and techniques to study the problems in this area are formed within the framework of these sciences. Environmental psychology deals with the researches in the field of the personality's environmental consciousness, reveals various types of a human's attitude to the world and also studies the personality's environmental consciousness evolution in the focus of developmental psychology. It is environmental pedagogy that exists at the intersection with environmental psychology. It works out the techniques of the personality's environmental consciousness development, taking the personality's age peculiarities into account. The main methods of environmental psychology are psychological diagnostics, allowing to evaluate the degree of the personality's existence in harmony with the world around; an experiment, allowing to determine the nature of the impact of educational techniques on the personality's environmental consciousness development, in particular, the associative experiment, allowing to reveal a human's unconscious attitudes towards nature (Kolesnik, 2016, Libakova, 2014) and other types of experiments; in addition, this science also uses other general scientific methods. The importance of field studies to solve a large spectrum of scientific problems in this research area does not diminish (Koptseva et al., 2016c). Environmental sociology, in its turn, studies the interaction of social systems and the surrounding world: the content-analysis, sociological surveys (Sertakova et al., 2015, Seredkina, 2014), visual anthropology (Libakova et al., 2016) and other methods (Koptseva et al., 2016a) in the framework of this science identify the problems of a human's negative influence on the world, search for the ways of a human's harmonious coexistence with nature (Koptseva et al., 2015, Seredkina, 2016). Environmental sociology bases on different versions of modern theories of social values (Bukova, 2014). Environmental sociology actively applies the methods of moderation and design, offers utopian and ideal variants for the integration of human society in the world - there 
appear the concepts of "garden city", "green city", etc. (Amosov et al., 2012, Reznikova et al., 2016). On the whole, environmental sociology aplies the activity-based approach to solve some of its problems (Kirko et al., 2010). For example, the festivals of environmental art, recycle art festivals have become recently widespread. They familiarize ordinary citizens with the conception of reappraisal of their behavior from the point of view of environmental benefit, advance the idea of recycling waste to decorate the cities, in particular (Kistova et al., 2016, Koptseva et al., 2016b). Finally, environmental cultural studies has been focusing on the history of a human's cultural interaction with nature. It applies the historical approach for the research of positive and negative experience of a human's coexistence with nature in order to avoid mistakes in the future and make use of positive examples (Avdeeva, Libakova, 2015, Luzan, 2016, Pimenova, 2012, Pimenova, 2016). Environmental cultural studies also applies the methods of other humanitarian environmental sciences - psychological diagnostics, public opinion poll, experiment, etc., using these techniques to solve its goals and objectives (Libakova, 2016, Reznikova, 2015, Koprseva and Sertakova, 2015).

It is obvious that one of the key methods to study the population's attitude towards climate changes is the content analysis, which makes it possible to get an idea of the view formed by the media on this issue. Modern social sciences almost completely deny the possibility of direct influence ("the position of the press = the reader's perception"), at least, regarding printed press and television. Yet, the method of content analysis makes it possible to get an idea of what picture is intentionally created by various media on the issue of climate changes, to evaluate who gets the benefits in this process and what benefits these are. In Western science the method of content analysis of the press highlighting the problems of climate changes is applied quite often: for example, J. Metag's paper generally describes its advantages for evaluation of the population's attitude towards climate changes as well as a strategy for the preparation of the qualitative content analysis. The content analysis of the press or educational literature often results in the conclusion that there is a gap between modern scientific data on climate changes and the picture of the world formed by the press focusing on the problem of climate changes and global warming: uninformed journalists' positions are either alarmist, driving the readers to fear from the impending changes, or, conversely, extremely relaxed and irresponsible, far from calling on individual citizens to participate in reducing an anthropogenic impact on the world (M.T. Boykoff, M. Mansfield, J. Thomas). An example of an ideal content analysis regarding this issue is D.M. Dotson and S.K. Jacobson's research, the results of which were published in the paper "Media Coverage of Climate Change in Chile: a Content Analysis of Conservative and Liberal Newspapers". While analyzing the printed press, the researchers have found a correlation between political interests and attitudes towards the issues of climate changes and global warming. They found out that the liberal press gives a twice broader and a more detailed coverage of this problem (the articles on this issue are published twice often and their scope is twice larger) and makes it vivid, providing the articles with visual materials, whereas the conservative press gives only little attention to the issue of climate change, scarcely illustrating the articles.

To solve the second problem - the development of a technique to evaluate the Krasnoyarsk Krai population's attitude towards climate changes and new energy sources - we studied various methods of the personality's environmental consciousness diagnostics, social public opinion polls and variants of surveys 
to collect expert opinions on this issue. In the course of the analysis of numerous Russian and foreign techniques of studying the population's attitude towards climate change and new sources of energy for adaptation several surveys for collection of sociological opinions were chosen to make a research among the population of Krasnoyarsk Krai.

The main survey bases on the "Survey of Environmental Concerns" developed by Dr. Lorraine Whitmarsh, Professor at School of Psychology (Cardiff University). This survey is addressed to ordinary citizens. It aims at finding out the citizens' shared concerns with the issues of climate changes and their attitude towards new energy sources and at determination of the citizens' readiness to consolidate their efforts to reduce an anthropogenic impact on climate changes. L. Whitmarsh's survey consists of several parts: the first one is a citizen's general awareness and concern with the issues of ecology and environment. This section lists the key environmental problems a human may face, the problems being air pollution, the holes in the ozone layer, floods, GMO products, etc. In this section the researcher also asks several questions about how closely the respondents faced (or are sure that they faced) environmental problems, whether he / she personally underwent the negative effects of air pollution or floods to get an idea of how abstract or specific the respondents' views on the subject of the research are. The second part of the survey contains the questions united under the title "Global environmental problems". In addition to the problems of climate changes proper there are a number of questions aiming at finding out the sources the recipients receive information about climate change from (scientific articles, tabloids, TV or specialized resources of world wildlife funds) and the extent of their critical attitude towards the information provided by various information sources: whether they trust any alarmist or another pseudoscientific resource or seeks to obtain the most complete and verified scientific data to form their own competent attitude towards the problem. The title of the third section is "General views on the environment". It aims to find out the extent of the interviewee's feeling of being a part of the natural world - whether he / she feels harmony with this world or considers him / herself a fully independent being whose existence has not any way affected the life of nature. Finally, in the last part of the survey the respondents need to answer some common personal questions regarding their age, education, etc. for the researcher to be able to establish a correlation of the personality's environmental consciousness and his / her social position. It should be noted that the maximum diversity of the survey techniques can be considered one of the advantages of the survey. It contains the questions requiring lengthy openended responses as well as the questions with "yes / no" answers and those requiring the ranking of the degree of confidence in the statement from "strongly agree" to "strongly disagree". The survey evenly distributes a number of questions to evaluate the personality's readiness to make a personal contribution to reducing an anthropogenic impact on nature - from the willingness to abandon personal transport to the readiness to use less powerful but renewable energy sources, deliberately reducing the degree of home comfort for the sake of reducing the environmental aggression.

Since common questions on the population's attitudes towards the environment seemed insufficient to describe the environmental socio-cultural situation in Krasnoyarsk Krai, we synthesized L. Whitmarsh's survey with an additional survey developed by the researches E. Ojomo, M. Elliot, U. Amjad, J. Bartram for Southern Nigeria. These researchers collected the respondents' information regarding their 
concern with specific environmental problems of their region - drought, reduction of water, reduction of shoreline, desertification, etc. By analogy with the questions for Southern Nigeria we added the questions on the issues of climate changes in Krasnoyarsk Krai - air pollution by large industrial enterprises, introduction of "black sky" situation, problems of public transport availability for the population, increase in wind force in Krasnoyarsk Krai, floods, etc. Moreover, to clarify the attitude of the heads of the government authorities and administrative managers of Krasnoyarsk Krai towards climate changes we borrowed an additional section from the survey developed by E. Ojomo, M. Elliot, U. Amjad, J. Bartram that could result in getting a full picture of the readiness of the krai to face the challenges of climate changes. At this stage we plan to evaluate the management office representatives' awareness on the issues of climate changes, as well as to make a comparative analysis of the level of the ordinary citizens' and administrative managers' environmental consciousness.

The third part of our research focused on the development of a survey for the executives and managers of organizations (transport companies, engineering and construction companies, industrial companies, etc.) who are directly or indirectly involved in the processes of an anthropogenic impact on nature. To compile this section we were guided by the sample developed by European concrete platform. This part of the research is obviously the most difficult as its questions should be addressed to competent employees of industrial enterprises, who are well-informed of what impact climate changes may have on their companies, what measures can be taken by the state and what developments the researchers can offer to reduce the degree of the companies' negative impact on the environment. In this section the respondents need to base on the specific data (state standards, static data, and numerical information) that describe their company's impact on the environment.

The synthesis of the three modern surveys - those by L. Whitmarsh, by E. Ojomo, M. Elliot, U. Amjad and J. Bartram, and by European concrete platform - resulted in the development of a survey to evaluate the Krasnoyarsk Krai population's attitude towards climate changes and new energy sources that will make it possible to find out the degree of the citizens' awareness of an anthropogenic impact on the environment, the degree of the citizens' willingness to make their personal contribution to the reduction of this impact, as well as the degree of the administrative managers' and industrial companies' readiness to face the challenges of climate changes.

\section{Conclusion}

The research resulted in the following conclusions:

1. The population's attitude towards climate changes and new energy sources are evaluated by the researchers in the field of environmental psychology, environmental sociology and environmental cultural studies that can be jointly regarded as the humanities with environmental focus.

2. Methodological approaches of these sciences intersect; the general scientific bibliographic analysis, the historical approach to evaluate the results of a human's interaction with nature in historical perspective, the axiological approach with different techniques of psychological diagnostics and opinion polls to find out the degree of a human's environmental awareness and attitude towards the world are of current interest for them; environmental sociology which focuses on modeling of a human's harmonious cooperation with the world 
also uses the activity approach to plan social events shaping an environmentally conscious personality.

3. The method of content analysis is particularly relevant in the framework of these sciences, as public opinion on the issue of climate changes and attitude towards new sources of energy is often formed via Internet resources, press and TV. With proper planning, the content analysis makes it possible to know how correct the estimate of current climate changes and environmental conditions, which is formed in mass media, is; who lobbies the promotion of certain beliefs on environmental problems in society and what is the purpose of this lobbying; whether publications in mass media have impact on the society and how serious it is, etc.
4. The synthetic methodology was developed for the analysis of the Krasnoyarsk Krai population's attitude towards climate changes and new energy sources. This methodology is an alloy of psychological diagnostics of the personality's environmental consciousness, a sociological survey on the issue of public awareness of environmental issues and the population's willingness to make their individual contribution to the reduction of an anthropogenic impact on nature. To obtain a holistic picture of the Krasnoyarsk Krai population's attitude to these issues we have developed three types of surveys - for ordinary citizens, for the heads of governmental authorities and administrative managers and for the managers of large industrial enterprises.

\section{References}

Alimov, A.A., Karlin, L.N., Muzalevskij, A.A., Samusevich, I.N., Gusakova, M.A. (2011). Climate of the Earth - Mythos and Reality, In Bezopasnost' Zhiznedeiatel'nosti [Vital Activity Security], 2, 1-24.

Amosov, A.E., Bokova, V.I., Bakhova, N.A., (2012). Indigenous and Small in Number Peoples of the North Siberia under the Global Transformations (on the Material of the Krasnoyarsk Territory). Conceptual and Methodological Basis of the Research. Ethno-cultural Dynamics of Indigenous Peoples of the Krasnoyarsk Territory (Part 1). Russia, Krasnoyarsk.

Avdeeva, Iu.N., Libakova, N.M. (2015). Mezhdunarodnye praktiki sotsiokul'turnogo proektirovaniia po otnosheniiu k korennym malochislennym narodam Severa, Sibiri i Dal'nego Vostoka [International Practices of Socio-Cultural Planning in Relation to the Indigenous Peoples of the North, Siberia and the Far East], In Sociodynamics, 10, 10-38. DOI: 10.7256/2409-7144.2015.10.1643. Available at: http://e-notabene.ru/pr/article_16430.html

Barker, R.G. (1968). Ecological Psychology: Concepts and Methods for Studying Environment of Human Behavior. Stanford, CA, Stanford University Press, 242 p.

Berkes, F. (1999). Sacred Ecology, Traditional Ecological Knowledge and Resource Management. Philadelphia, $209 \mathrm{p}$.

Boykoff, M.T., Mansfield M. (2008). 'Ye Olde Hot Aire': Reporting of Human Contributions to Climate Change in the UK Tabloid Press, In Environmental Research Letters, 3. Available at: http:// iopscience.iop.org/article/10.1088/1748-9326/3/2/024002/pdf

Bukova, M.I. (2014). Nekotorye aspekty teorii sotsial'nykh tsennostei [Some Aspects of the Theory of Social Values], In Sociodynamics, 12, 78-89. DOI: 10.7256/2409-7144.2014.12.1390. Available at: http://e-notabene.ru/pr/article_13901.htm

Deriabo, S.D. (1999). Ekologicheskaia psikhologiia: diagnostika ekologicheskogo soznaniia [Environmental Psychology: Diagnostics of Environmental Consciousness]. Moscow, 310 p. 
Dotson, D.M., Jacobson, S.K. (2012). Media Coverage of Climate Change in Chile: a Content Analysis of Conservative and Liberal Newspapers, In Enviromental Communication, 6(1). Available at: http://www.tandfonline.com/doi/abs/10.1080/17524032.2011.642078

Gibson, J.J. (1979). The Ecological Approach to Visual Perception. Boston, 332 p.

Glebov, V.V. (2008). Ekologicheskaia psikhologiia [Ecological Psychology]. Moscow, RUDN University. Available at: http://web-local.rudn.ru/web-local/uem/iop_pdf/102-Glebov.pdf

Guseva, A.Iu., Zhuravlev, A.L. (2002). Programma Sotsial'no-Psikhologicheskikh Issledovanii Ekologicheskogo Soznaniia Cheloveka [The Programme of Social-Psychological Research of a Human's Ecological Consciousness]. In Sovremennaia psikhologiia: sostoianie I perspektivy issledovanii [Contemporary Psychology: State and Prospects]. Moscow, Institute of Psychology of the Russian Academy of Science, 231-250.

Ignatov, S.B. (2012). Ecological Culturology. Tyumen, 28 p. Available at: http://www.tyuiu.ru/ media/files/2013/01_15/mu_ekologicheskaya_kulturologia.pdf

Ignatova, V.A. (2016). To the Problem about the Transdisciplinarity of Ecological Culturology, In Herald of the International Academy of Science. Russian Section, 1, 44-47. Available at: http://www. heraldrsias.ru/download/articles/07_Ignatova.pdf

Kirko, V.I., Bukharov, A.V., Keusch, A.V. (2010). Evaluation of the Innovative Potential of the Typical Territorial and Administrative Units of Krasnoyarsk Krai, In Innovations, 12, 78-83.

Kistova, A.V., Zamaraeva, J.S., Pimenova, N.N., Reznikova, K.V., Koptseva, N.P., Seredkina, N.N. (2016a). Regional Peculiarities in Modernization Processes within the Territories of Central Siberia, In International Review of Management and Marketing, 6 (4), 857-865.

Kistova, A.V., Moskalyuk, M.V., Sertakova, E.A., Dvoretskaya, A.P. (2016). The Use of the Name of Vasilii Ivanovich Surikov for the Construction of a Positive Image of Krasnoyarsk, In NB: Administrative Law and Administration Practice, 6, 1-13. DOI: 10.7256/2306-9945.2016.6.20967. Available at: http://e-notabene.ru/al/article_20967.html

Kolesnik, M.A. (2016). Peculiarities of Perception of the Russian Ethnos among Youth of Krasnoyarsk According to the Results of the Associative Experiments Using the word "Russian", In Sociodynamics, 4, 59-67. DOI: 10.7256/2409-7144.2016.4.18270. Available at: http://e-notabene.ru/pr/ article_18270.html

Koptseva, N.P. Sertakova, E.A. (2015). To the Question of Methodological Strategy of the Modern Urban Anthropology, In Gumanitarnye i Sotsial'nye Nauki [Humanities and Social Sciences], $1,103-120$.

Koptseva, N.P., Zamarayeva, Yu.S., Kirko, V.I. (2015). Characteristic Features of Ethnic Labor Migration in the Krasnoyarsk Krai (Central Siberia, Russia), In International Journal of Economics and Financial Issues, 5 (2S), 100-108.

Koptseva, N.P., Zamaraeva, Yu.S., Kistova, A.V., Pimenova, N.N., Seredkina, N.N., Reznikova K.V., Fil'ko A. (2016b). Place Management: Decoding the Visual Image of a Siberian City, In Journal of Applied Economic Sciences, 11(6), 1144-1156.

Koptseva, N.P., Kirko, V.I., Nevzorov, V.N., Bukharova, E.B., Razumovskaya, V.A., Semenova, A.R. (2016c). Traditional Nature Management Areas as Means of Organizing the Economic Activities of the Siberian Arctic's Indigenous Minorities, In International Review of Management and Marketing, 6 (S5), 154-161. 
Lauwerys, J.A. (1969). Man's Impact on Nature. London, 188 p.

Libakova, N.M. (2014). Social and Psychological Peculiarities of Formation of Gender Roles of Russian Students (Results of the Association Experiment), In Sociodynamics, 10, 101-134. DOI: 10.7256/2306-0158.2014.10.1343. Available at: http://e-notabene.ru/pr/article_13435.html

Libakova, N.M. (2016). Acculturative Stress and Techniques for Overcoming It, In Sociodynamics, 2, 89-97. DOI: 10.7256/2409-7144.2016.2.17683. Available at: http://e-notabene.ru/pr/article_17683.html

Libakova, N.M. Sertakova, E.A., Kolesnik, M.A., Sitnikova, A.A., Il’beikina, M.I. (2016). Modern Strategies of the Social Positioning of Siberian Regions, In Sociodynamics, 1, 162-189. DOI: 10.7256/2409-7144.2016.1.17420. Available at: http://e-notabene.ru/pr/article_17420.html.

Luzan, V.S. (2016). To the Question of the Effect of Cultural Policy upon the Modern Local Identities, In Sociodynamics, 2, 47-66. DOI: 10.7256/2409-7144.2016.2.17733. Available at: http://enotabene.ru/pr/article_17733.html

Makarova, L.M. (2014). Ekologicheskaia Psikhologiia i Pedagogika [Ecological Psychology and Pedagogy]. Samara, 123 p.

Metag, J. (2016). Content Analysis Methods for Assessing Climate Change Communication and Media Portrayals, In Climate Science. Oxford Research Encyclopedias. DOI: 10.1093/ acrefore/9780190228620.013.486

Moser, S.C. (2006). Talk of the City: Engaging Urbanities on Climate Change, In Environmental Research Letters, 1. Available at: http://iopscience.iop.org/article/10.1088/1748-9326/1/1/014006/pdf

Ojomo, E., Elliot, M., Amjad, U., Bartram, J. (2015). Climate Change Preparedness: a Knowledge and Attitudes in Southern Nigeria, In Environments, 2, 435-448. DOI: 10.3390/environments2040435

Park, R.E. (1952). Human Communities: the City and Human Ecology. London, 278 p.

Pimenova, N.N. (2012). Problemy Obrazovaniia Detei Korennykh Malochislennykh Narodov Sibiri i Severa v Krasnoiarskom Krae [Educational Problems of Children of Indigenous Peoples of Siberia and North in the Krasnoyarsk Region], In Innovatsii v Nepreryvnom Obrazovanii [Innovations in Continuing Education], Russia, 5, 12-18.

Pimenova, N.N. (2016). Mechanisms of Sociocultural Changes of the Indigenous People of Siberia and North: Concept of Cultural Trauma by Piotr Sztompka, In Sociodynamics, 3, 37-45. DOI: 10.7256/2409-7144.2016.3.18210. Available at: http://e-notabene.ru/pr/article_18210.html

Redclift, M.L. (2010). The International Handbook on Environmental Sociology. Second edition. 448 p.

Reznikova, K.V. (2015). Ethnicity as Category of Social Knowledge, In Sociodynamics, 1, 101-111. DOI: 10.7256/2409-7144.2015.1.14228. Available at: http://e-notabene.ru/pr/article_14228.html

Reznikova, K.V., Pimenova, N.N., Kistova, A.V., Seredkina, N.N., Zamaraeva, Yu.S. (2016). Management of the Siberian Territory Branding in the Light of the "New Regionalism", In Sociodynamics, 1, 137-161. DOI: 10.7256/2409-7144.2016.1.17395. Available at: http://e-notabene.ru/ pr/article_17395.html

Seredkina, N.N. (2014). Ethnic Picture of the World in the Framework of Modern Social Research, In Sociodynamics, 10, 26-59. DOI: 10.7256/2306-0158.2014.10.1344. Available at: http://e-notabene.ru/ pr/article_13441.html

Seredkina, N.N. (2016). The Theoretical Model of Positive Ethnic Identity and the Mechanisms of Its Formation, In Sociodynamics, 2, 37-46. DOI: 10.7256/2409-7144.2016.2.17690. Available at: http:// e-notabene.ru/pr/article_17690.html 
Sertakova, E.A., Zamaraeva, Yu.S., Sitnikova, A.A. (2015). A Sociological Study of Cultural Needs of the Residents of Krasnoyarsk, In Urban Studies, 3, 16-42.

Simmons, I.G. (1989). Changing the Face of the Earth: Culture, Environment, History. Blackwell, $484 \mathrm{p}$.

Sitarov, V.A., Pustovoitov, V.V. (2000). Sotsial'naia Ekologiia [Social Ecology]. Moscow, 280 p. Available at: https://lib.bsu.edu.ge/e-books/book_171.pdf

Sterligova, E.A. (2012). Ekologicheskaia Psikhologiia [Ecological Psychology]. Perm, 212 p. Available at: http://www.psu.ru/files/docs/personalnye-stranitsy-prepodavatelej/sterligova/ ekopsihologija_uch_posobie.pdf

Thomas, J. (2015) Climate Change Skeptics Teach Climate Literature? A Content Analysis of Children's Books, In DBER Speaker Series. Paper 77. Available at: http://digitalcommons.unl.edu/cgi/ viewcontent.cgi?article $=1075 \&$ context $=$ dberspeakers

Twinomugisha, B. (2005). A Content Analysis Reports on Climate Change Impacts, Vulnerability and Adaptation in Uganda. Available at: http://pubs.iied.org/pdfs/10011IIED.pdf

Vernadskii, V.I. (2012). Biosfera i Noosfera [Biosphere and Noosphere]. Moscow, 576 p.

Whitmarsh, L. (2008). Are Flood Victims More Concerned about Climate Change Than Other People? The Role of Direct Experience in Risk Perception and Behavioural response, In Journal of Risk Research, 11 (3), 351-374.

Whitmarsh, L. (2009a). Behavioural Responses to Climate Change: Asymmetry of Intentions and Impacts, In Journal of Environmental Psychology, 29 (1), 13-23.

Whitmarsh, L. (2009b). What's in a Name? Commonalities and Differences in Public Understanding of "Climate Change" and "Global Warming", In Public Understanding of Science, 18 (4), 401-420.

Whitmarsh, L. (2011). Scepticism and Uncertainty about Climate Change: Dimensions, Determinants and Change over Time, In Global Environmental Change, 21 (2), 690-700.

\title{
Выбор методологии и методики для анализа \\ отношения населения Красноярского края
}

к изменениям климата и новым источникам энергии

\author{
А.А. Ситникова \\ Сибирский федеральный университет \\ Россия, 660041, Красноярск, пр. Свободный, 79
}

В статье описаны ключевые методологические подходы и методики таких наук, как «экологическая психология», «экологическая сочиология» и «экологическая культурология», - исторический подход, библиографический анализ, деятельностный подход с проектированием сочиальных событий, формирующий экологическое сознание личности, психологические диагностики, сочиологический опрос, сбор экспертных мнений, контент-анализ и др. На основе анализа преимуществ и недостатков различных методологий осуществлен выбор методики для анализа отношения населения Красноярского края к изменениям климата и новым источникам энергии, в качестве которой стала синтетическая методика, полученная в результате работы с анкетой для психологической диагностики экологического сознания личности L. Whitmarsh, 
дополнения ее специфическими экологическими проблемами Красноярского региона - загрязнение воздуха крупными индустриальными предприятиями, введение режима «черное небо», последствия работы гидроэлектростанции на реке Енисей и другие аспекты, а также создания анкет для сбора экспертных мнений - во-первых, для административных менеджеров (на основе анкетирования ученых E. Ojoто, M. Elliot, U. Amjad, J. Bartram для Южной Нигерии) u, во-вторых, для руководителей крупных индустриальных предприятий (на основе опроса European concrete platform).

Ключевые слова: экологическая психология, экологическая сочиология, экологическая культурология, психологическая диагностика экологического сознания личности, отношение населения Красноярского края к климатическим изменениям.

Исследование выполнено при финансовой поддержке Российского фонда фундаментальных исследований, Правительства Красноярского края, Красноярского краевого фонда поддержки научной и научно-технической деятельности в рамках научного проекта № 17-16-24601.

Научная специальность: 24.00.00 - культурология.

APPENDIX

Survey 1. A survey of the Krasnoyarsk Krai citizens on the issue of their attitude towards climate changes and new energy sources

Section 1. General questions regarding the citizens' concern about environmental problems

1. Please, look through the list of environmental problems and underline three problems you are mostly worried with. Please, choose only three problems you consider the most urgent:

- Air pollution;

- Pollution of rivers, lakes and seas;

- Flooding;

- Garbage;

- Mismanagement of waste (e.g. overfull refuse dumps);

- Traffic / Traffic jams;

- GMO products;

- Climate change;

- Holes in the ozone layer;

- Overuse of natural resources;

- Extinction of species;

- Radioactive waste;

- Overflow of population (of the Earth).

2. Do you think air pollution has affected your health somehow?

- Yes:

- No;

- I don’t know.

3. Has air pollution affected your family members or friends somehow?

- Yes;

- No;

- I don't know.

4. Are you aware of the impacts of air pollution other than the impact on health?

- Yes (go to question 5);

- No (go to question 6);

- I don't know (go to question 6).

5. If yes, what other impacs of air pollution are you aware of? 
6. Have you experienced the consequences of any kind of flooding (including your house, garden, vehicles) in the course of the last 5 years?

- Yes;

- No;

- I don't know.

7. Do you feel that the weather conditions have generally changed?

- Yes (go to question 8);

- $\quad$ No (go to question 9);

- I don't know (go to question 9).

8. If yes, why do you think this could happen?

Section 2. Global environmental problems

9. Have you ever heard about "climate changes"?

- Yes (go to question 10);

- $\quad$ No (go to question 25);

- I don't know (go to question 25);

10. What do you know about this?

11. Where did you hear about "climate changes"? Mark all the variants that are true for you

- TV;

- Radio;

- Newspapers;

- Internet;

- Specialists' publications / Scientific journals;

- Organizations for the protection of the environment (e.g. World Wildlife Fund);

- School / Vocational school / University;

- State Agencies / State information;

- Public libraries;

- Friends / Family;

- Regional government;

- Energy supply;

- Other (please, specify)

12. Painting out a box in each line, mark the degree of your trust to the information about climate changes if you heard it from...

\begin{tabular}{|l|l|l|l|l|}
\hline & Strongly & Partly & Not much & Would not trust at all \\
\hline A family member or a friend & & & & \\
\hline Scientist & & & & \\
\hline Government & & & & \\
\hline Energy supply & & & & \\
\hline $\begin{array}{l}\text { Organizations for the protection } \\
\text { Wildlife Fund) } \\
\text { Wild }\end{array}$ & & & & \\
\hline \begin{tabular}{l} 
Media (TV, radio, newspapers) \\
\hline
\end{tabular} & & & & \\
\hline
\end{tabular}


13. How important are the problems of climate changes personally for you?

- Very important (go to question 14);

- Quite important (go to question 14);

- $\quad$ Not much important (go to question 15);

- Have no importance at all (go to question 15).

14. Why are they important for you?

15. What is the reason of climate changes, to your mind?

16. What kind of influence can climate changes have, if such is possible, to your mind?

17. Do you think that climate changes are something that influences you personally or can have such an influence in the future?

- Yes (go to question 18);

- No (go to question 19);

- I don't know (go to question 19).

18. If yes, what influence do they have on you personally or might they have on you in the future?

19. Do you think that some measures could be done to solve the problem of climate changes?

- Yes (go to question 20);

- $\quad$ No (go to question 22);

- I don't know (go to question 22).

20. If yes, what can be precisely done to solve the problem of climate changes?

21. Who do you think should take primary responsibility for solving the problem of climate changes? (please, choose only ONE option)

- International organizations (e.g. UN);

- Federal government;

- Regional government;

- Business and industries;

- Organizations for the protection of the environment (e.g. World Wildlife Fund);

- Citizens;

- Other (please, specify who ) .

22. Have you ever acted, or do you regularly act, out of your concern for climate changes?

- Yes (go to question 23);

- No (go to question 24);

- I don't know (go to question 24);

23. If yes, what have you done for this / or what do you do for this?

24. Please, mark how strongly you agree or disagree with the following statements by ticking one of the boxes in each line:

\begin{tabular}{|l|l|l|l|l|l|}
\hline & $\begin{array}{c}\text { Fully } \\
\text { agree }\end{array}$ & Agree & $\begin{array}{c}\text { Neither agree } \\
\text { nor disagree }\end{array}$ & Disagree & $\begin{array}{c}\text { Fully } \\
\text { disagree }\end{array}$ \\
\hline $\begin{array}{l}\text { We all can do a bit to reduce the negative effects of } \\
\text { climate changes }\end{array}$ & & & & & \\
\hline $\begin{array}{l}\text { Climate changes are inevitable provided that modern } \\
\text { society is geared so }\end{array}$ & & & & & \\
\hline $\begin{array}{l}\text { People need to reduce energy consumption if it will } \\
\text { stop climate changes }\end{array}$ & & & & & \\
\hline $\begin{array}{l}\text { Climate changes will improve weather conditions in } \\
\text { Krasnoyarsk Krai }\end{array}$ & & & & \\
\hline
\end{tabular}


Alexandra A. Sitnikova. The Choice of Methodology and Techniques for the Analysis of the Krasnoyarsk Krai Population's...

\begin{tabular}{|c|c|c|c|c|c|}
\hline & $\begin{array}{l}\text { Fully } \\
\text { agree }\end{array}$ & Agree & \begin{tabular}{c|} 
Neither agree \\
nor disagree
\end{tabular} & Disagree & $\begin{array}{c}\text { Fully } \\
\text { disagree }\end{array}$ \\
\hline \multicolumn{6}{|l|}{$\begin{array}{l}\text { Climate changes are a natural fluctuation of the } \\
\text { Earth's temperature }\end{array}$} \\
\hline \multicolumn{6}{|l|}{$\begin{array}{l}\text { I will make my small contribution to the process of } \\
\text { climate change suspension only if everybody will do } \\
\text { the same }\end{array}$} \\
\hline \multicolumn{6}{|l|}{$\begin{array}{l}\text { The government must offer the people certain } \\
\text { measures they can take to care for the environment }\end{array}$} \\
\hline \multicolumn{6}{|l|}{ It is too late to do anything to stop climate changes } \\
\hline \multicolumn{6}{|l|}{$\begin{array}{l}\text { Human activity does not significantly affect global } \\
\text { warming }\end{array}$} \\
\hline \multicolumn{6}{|l|}{ Climate changes are something that scares me } \\
\hline \multicolumn{6}{|l|}{$\begin{array}{l}\text { Developing countries are most responsible for climate } \\
\text { changes }\end{array}$} \\
\hline \multicolumn{6}{|l|}{ I am not sure that climate changes do take place } \\
\hline \multicolumn{6}{|l|}{$\begin{array}{l}\text { Only radical changes in the society can solve the } \\
\text { climate change problems }\end{array}$} \\
\hline \multicolumn{6}{|l|}{$\begin{array}{l}\text { People are too selfish to do anything to solve climate } \\
\text { change problems }\end{array}$} \\
\hline \multicolumn{6}{|l|}{ Data on current climate changes are too unreliable } \\
\hline \multicolumn{6}{|l|}{$\begin{array}{l}\text { Major industrialized states are most responsible for } \\
\text { climate changes }\end{array}$} \\
\hline \multicolumn{6}{|l|}{$\begin{array}{l}\text { The statement, that climate changes are caused by } \\
\text { intensive human activities, is exaggerated }\end{array}$} \\
\hline \multicolumn{6}{|l|}{$\begin{array}{l}\text { If I run across the information about climate } \\
\text { statements, I will certainly look through it }\end{array}$} \\
\hline \multicolumn{6}{|l|}{$\begin{array}{l}\text { Nowadays there is too much contradictory } \\
\text { information about climate changes to make a } \\
\text { conclusion about whether they really take place or not }\end{array}$} \\
\hline \multicolumn{6}{|l|}{$\begin{array}{l}\text { The fact that I do not turn off the light at home affects } \\
\text { climate changes }\end{array}$} \\
\hline \multicolumn{6}{|l|}{ Climate changes are consequences of modern life } \\
\hline \multicolumn{6}{|l|}{$\begin{array}{l}\text { The negative impact of climate changes is likely to be } \\
\text { catastrophic }\end{array}$} \\
\hline \multicolumn{6}{|l|}{$\begin{array}{l}\text { It is absolutely impossible that all my actions change } \\
\text { the climate }\end{array}$} \\
\hline \multicolumn{6}{|l|}{$\begin{array}{l}\text { Industrial pollution is the main cause of climate } \\
\text { changes }\end{array}$} \\
\hline \multicolumn{6}{|l|}{$\begin{array}{l}\text { I am inclined to believe that the information about } \\
\text { climate changes has nothing to do with me }\end{array}$} \\
\hline \multicolumn{6}{|l|}{$\begin{array}{l}\text { Recent floods in the country were due to climate } \\
\text { changes }\end{array}$} \\
\hline \multicolumn{6}{|l|}{$\begin{array}{l}\text { It is too early to consider climate changes a real } \\
\text { problem }\end{array}$} \\
\hline \multicolumn{6}{|l|}{$\begin{array}{l}\text { Mass media often unnecessarily raise the alarm about } \\
\text { the problems like climate changes }\end{array}$} \\
\hline \multicolumn{6}{|l|}{$\begin{array}{l}\text { The number of floods has not increased, these are the } \\
\text { reports in the mass media that increased in our days }\end{array}$} \\
\hline $\begin{array}{l}\text { There is no point to take any action to prevent climate } \\
\text { changes as no one does anything for this }\end{array}$ & & & & & \\
\hline
\end{tabular}


Alexandra A. Sitnikova. The Choice of Methodology and Techniques for the Analysis of the Krasnoyarsk Krai Population's...

\begin{tabular}{|l|l|l|l|l|l||}
\hline & $\begin{array}{c}\text { Fully } \\
\text { agree }\end{array}$ & Agree & $\begin{array}{l}\text { Neither agree } \\
\text { nor disagree }\end{array}$ & Disagree & $\begin{array}{c}\text { Fully } \\
\text { disagree }\end{array}$ \\
\hline $\begin{array}{l}\text { Experts agree that climate changes are a really urgent } \\
\text { problem }\end{array}$ & & & & & \\
\hline $\begin{array}{l}\text { None of my daily activities has any effect on the } \\
\text { current climatic changes }\end{array}$ & & & & & \\
\hline $\begin{array}{l}\text { Industry and business must do more to tackle climate } \\
\text { change problems }\end{array}$ & & & & & \\
\hline $\begin{array}{l}\text { On a large scale, the government honestly tries to halt } \\
\text { climate changes }\end{array}$ & & & & & \\
\hline $\begin{array}{l}\text { I do not believe that climate changes are really a } \\
\text { problem }\end{array}$ & & & & & \\
\hline $\begin{array}{l}\text { The government sufficiently addresses the problem of } \\
\text { climate changes }\end{array}$ & & & & & \\
\hline $\begin{array}{l}\text { I feel a moral responsibility for suspending climate } \\
\text { changes somehow }\end{array}$ & & & & & \\
\hline
\end{tabular}

Section 3. General views on the environment

25. Now, please, mark the degree of your agreement or disagreement with the following statements by ticking one box in each line:

\begin{tabular}{|l|l|l|l|l|l||}
\hline $\begin{array}{l}\text { The work at present is much more important than } \\
\text { planning the future environment }\end{array}$ & $\begin{array}{c}\text { Fully } \\
\text { agree }\end{array}$ & Agree & $\begin{array}{c}\text { Neither agree } \\
\text { nor disagree }\end{array}$ & Disagree & $\begin{array}{c}\text { Fully } \\
\text { disagree }\end{array}$ \\
\hline $\begin{array}{l}\text { I do not wish to make personal sacrifices for the } \\
\text { benefit of the environment }\end{array}$ & & & & & \\
\hline $\begin{array}{l}\text { If my job caused environmental problems, I would } \\
\text { rather prefer to resign than to continue to cause these } \\
\text { problems }\end{array}$ & & & & & \\
\hline Having a car is a part of a good lifestyle & & & & & \\
\hline $\begin{array}{l}\text { People have the right to change the environment for } \\
\text { the environment to satisfy their needs }\end{array}$ & & & & & \\
\hline People ill-treat the planet & & & & & \\
\hline $\begin{array}{l}\text { Plants and animals have the same rights for existence } \\
\text { that the humans have }\end{array}$ & & & & & \\
\hline $\begin{array}{l}\text { Nature is strong enough to cope with the influence of } \\
\text { modern industrial states }\end{array}$ & & & & & \\
\hline People were created to dominate the rest of nature & & & & & \\
\hline Natural balance is very fragile and easy to break & & & & \\
\hline
\end{tabular}

26. Further follows a list of activities you might be involved in. For every activity you do REGULARLY tick the reason why you do it. Tick all such activities:

I get to work on foot or by bike (convenience, saving money, protecting the environment, for my health, habit, moral obligation, other (please, specify) ).

I use public transport (convenience, saving money, protecting the environment, for my health, habit, moral obligation, other (please, specify) ).

I turn off the light when it is not in use (convenience, saving money, protecting the environment, for my health, habit, moral obligation, other (please, specify) ). 
I buy energy saving light bulbs (convenience, saving money, protecting the environment, for my health, habit, moral obligation, other (please, specify) ).

I buy organic food (convenience, saving money, protecting the environment, for my health, habit, moral obligation, other (please, specify) ).

I have glass containers processed (convenience, saving money, protecting the environment, for my health, habit, moral obligation, other (please, specify)

I have other items recycled (convenience, saving money, protecting the environment, for my health, habit, moral obligation, other (please, specify) ).

I participate in the campaigns on environmental issues (convenience, saving money, protecting the environment, for my health, habit, moral obligation, other (please, specify)

Section 4. Attitude towards environmental problems at the local level (in Krasnoyarsk Krai)

27. How would you rate the quality of public transport in your city?

- Excellent;

- Good;

- Average;

- Poor;

- Very bad;

- I don't know.

28. What problem connected with the climate changes in Krasnoyarsk Krai worries you most (choose only ONE problem that worries you most)

- No freeze-up of the Yenisei;

- Floods and flooding;

- Frequent winds and wind power;

- Introduction of "black sky" situation;

- The level of industrial influence on the environment (emissions of RUSAL, municipal heat electric generation plant, etc.);

- Air pollution by motor vehicle emissions;

- Other (please, specify).

29. Who do you think should take measures to prevent climate changes in Krasnoyarsk Krai:

- Federal government;

- Krai government;

- Industrial enterprises;

- Private business;

- Organizations for the protection of the environment;

- Motor vehicle owners;

- Citizens;

- Other (please, specify ).

\section{Section 5}

Finally, could you kindly tell us about yourself for us to have an opportunity to compare different people's views:

30. You are ...

A) Male;

Б) Female;

B) I prefer not to specify. 
31. Please, specify your age:

- $16-24$;

- $25-34 ;$

- $35-44$;

- $45-54$

- $55-64$;

- $65-74$;

- $75-84$;

- Over 85;

- I prefer not to specify.

32. Your education level:

- Comprehensive secondary school;

- No professional education;

- Vocational / Vocational and training school;

- Higher education / Bachelor;

- Higher education / Master;

- Candidate or Doctor of Science;

- Other (please, specify ).

33. Which political party do you most likely support?

- Worker's party;

- Liberal democrats;

- Communists;

- Edinaia Rossiia (United Russia);

- Other (please, specify

- None;

- I prefer not to specify.

34. Do you have (or Do you regularly drive) your own car / truck?

- Yes (go to question 33);

- $\quad$ No (go to question 34).

35. If yes, specify the approximate number of kilometers you drive per year

36. Please, specify your annual income (approximately, without tax):

- $120000-150000$;

- $160000-250000$;

- $260000-350000$;

- $360000-450000$;

- $460000-550000$;

- $560000-650000$;

- $660000-750000$;

- More than 760 000;

- I prefer not to specify. 
37. Which of these newspapers do you read regularly? Mark as many as you read:

- Izvestiia;

- Kommersant;

- Vedomosti;

- Rossiiskaia Gazeta;

- Novaia Gazeta;

- Komsomol'skaia Pravda;

- Moskovskii Komsomolets;

- Argumenty i Fakty;

- Parlamentskaia Gazeta;

- Nezavisimaia Gazeta;

- Online newspapers and news websites (please, specify

- Krasnoyarsk newspapers (please, specify );

38. Are you a member of an organization for the protection of the environment (e.g., Friends of the Earth or the World Wildlife Fund)?

- Yes;

- No.

39. Would you like to take part in a brief interview (in person or by telephone) to discuss these problems seriously? All the information in the interview will be strictly confidential, as is the case with this survey.

- Yes;

- No;

If yes, give your telephone number, please

40. If you would like to get a copy of the results of this research, please, give your email or postal address here:

41. If you have something to add regarding the problems raised in this survey or comments regarding the survey itself, please, write them here:

Survey 2. A survey of the heads and managers of organizations (transport companies, engineering and construction companies, industrial companies, etc.)

1. What organization do you represent?

- $\quad$ Private business;

- Industrial enterprise;

- Other

2. What is your position in the organization

3. Which sector of economy is your organization a part of?

4. What are the international and national standards on preservation of climatic and environmental conditions for your organization?

5. What standards should be added / changed to reduce the degree of your company's influence on climate change?

6. What might be the changes in your industry caused by climate change in the short- and long-term perspective? (for example, caused by temperature changes, changes in rainfall, strength and frequency of winds, sea level rise, increase in the number of storms and wave heights, changes in the amount of snow and ice, sudden and severe floods)

7. Is it possible to make the infrastructure of your organization resistant to these climatic changes? What is needed for this? 
8. In addition to what is prescribed by national or international standards, are there other problems or concerns regarding climate changes that are important for the branch of industry your organization is a part of? Please, specify the key problems, describe their importance.

9. What aspects in the work of your organization are the most vulnerable with respect to climate changes? (For example, the characteristic features of the materials, interindustry collaboration, constructions (e.g., bridges), drainage and erosion, lack of funding and the need for setting up funds, local engineering problems and problems of the land use, technological problems, etc.)

10. Do any outdated standards pose a problem for the adaptation of your organization to current climate changes? Please, briefly describe why.

11. What effects of climate changes can be avoided or minimized by introducing well-known practices and methods of solving such problems to common standards?

Survey 3. The attitude of the Krasnoyarsk Krai heads of governmental institutions and administrative managers to climate changes

1. What ministry or official body do you represent?

2. What territory is ruled by your establishment or organization? Municipal / Rural / Both (underline the necessary).

3. How long have you been working for this establishment or organization?

- $0-5$ years;

- 6 - 10 years;

- $11-15$ years;

- More than 16 years.

4. Human activity leads to climate changes:

- Fully agree;

- Agree;

- I don't know;

- Disagree;

- Fully disagree;

- I do not believe that climate change takes place.

5. Natural variability leads to climate changes:

- Fully agree;

- Agree;

- I don't know;

- Disagree;

- Fully disagree;

- I do not believe that climate change takes place.

6. What are considered to be climate changes, to your mind (please, tick all the options you consider to be true):

- $\quad$ Rising of sea level;

- Drought;

- Floods;

- The coastline destruction;

- Increasing temperature;

- Melting of ice;

- Desertification;

- Increase in the intensity and frequency of extreme weather situations;

- None of the listed above;

- Other (please, specify 
7. Which of these phenomena have the greatest impact on climate changes in Krasnoyarsk Krai? (please, tick all the options you consider to be true):

- $\quad$ Rising of sea level;

- Drought;

- Floods;

- The coastline destruction;

- Increasing temperature;

- Melting of ice;

- Desertification;

- Increase in the intensity and frequency of extreme weather situations;

- None of the listed above;

- Other (please, specify

8. What practices are currently put into effect in order to reduce the negative impact of climate changes on water resources in Krasnoyarsk Krai? (please, tick all the options you consider to be true):

- Prevention of water contamination during flooding;

- Groundwater recharge;

- $\quad$ Reduction of the amount of water consumption for daily living needs;

- Environmental protection from the pollution of rivers and lakes of Krasnoyarsk Krai;

- Reduction of water consumption in agricultural and industrial units;

- None of the listed above;

- Other (please, specify ) ;

- I don't know.

9. What procedures are now implemented for saving water resources of Krasnoyarsk Krai in the light of the impact of climate changes? (please, tick all the options you consider to be true):

- Integration of knowledge about climate changes into water resources management processes;

- Cooperation of different industrial and administrative sectors to ensure the effective utilization of water resources in the production process;

- Running the campaigns informing about climate changes and their consequences;

- Research of the issues of adaptation to climate changes;

- Mobilization and involvement of the public in the processes of adaptation to climate changes;

- None of the listed above;

- Other (please, specify )

- I don't know.

10. Who should be responsible for financing of the processes of adaptation to climate changes in Krasnoyarsk Krai? (please, tick all the options you consider to be true):

- Federal government;

- International organizations (e.g. UN);

- Regional government;

- Organizations for the protection of the environment (for example, the World Wildlife Fund);

- Nongovernmental, nonprofit organizations established for this purpose (e.g., funds);

- Industrial enterprises;

- Krasnoyarsk Krai has no need in special measures for the adaptation to climate changes;

- Other (please, specify

- I don't know.

11. Do you know if there are any campaigns on raising the population's awareness about climate changes in Krasnoyarsk Krai?

- Yes (go to question 12);

- $\quad$ No (go to question 13).

12. What means are used for the campaigns on raising the population's awareness about climate changes in Krasnoyarsk region? (please, tick all the options you consider to be true):

- Leaflets;

- TV;

- Radio; 
- Internet resources;

- Newspapers / magazines;

- Gossips;

- Educational lectures at schools and universities;

- $\quad$ Other (please, specify

13. Choose only THREE environmental problems of ten ones listed below which are priority problems for Krasnoyarsk Krai:

- Over-population;

- Urbanization;

- Deforestation;

- Desertification;

- Air pollution;

- Education in the field of environmental issues;

- $\quad$ Recycling and disposal;

- Renewable energy;

- Preservation of water resources;

- Other (please, specify ) .

14. Which THREE main resources do you use to be informed about climate changes?

- Internet;

- Scientific conferences and lectures;

- TV;

- Newspapers / magazines;

- Radio;

- Religious leaders;

- State agencies;

- Non-governmental organizations;

- I have no preferable resources to get information about climate changes;

- $\quad$ Other (please, specify 